\title{
Screening for physicochemical incompatibilities of intravenous drugs in intensive care units: the case of monobasic potassium phosphate and furosemide
}

\author{
Valia Humbert-Delaloye, ${ }^{1,2}$ Markoulina Berger-Gryllaki, ${ }^{1}$ Pierre Voirol, ${ }^{1}$ Bernard Testa, ${ }^{1}$ \\ André Pannatier ${ }^{1,2}$
}

${ }^{1}$ Department of Pharmacy, University Hospital Centre (CHUV), Lausanne, Switzerland ${ }^{2}$ School of Pharmaceutical Sciences, University of Geneva and University of Lausanne, Geneva, Switzerland

\section{Correspondence to} Valia Humbert-Delaloye, Department of Pharmacy, Centre Hospitalier Universitaire Vaudois (CHUV), Rue du Bugnon 46, Lausanne 1011, Switzerland; valia.humbert-delaloye@chuv.ch

Received 11 December 2013 Revised 23 February 2014 Accepted 10 March 2014 Published Online First 15 April 2014

\section{ABSTRACT}

Objectives Physicochemical incompatibilities between intravenous drugs are a recurrent problem in hospital settings. Having observed a drug precipitation during Y-site administration in our intensive care units, we undertook an investigation to find out its cause. Methods We conducted a literature search on the injectable drugs involved in the observed precipitates and undertook laboratory physicochemical incompatibility testing of potentially incompatible drug combinations not reported in the literature.

Results Among the drugs tested, only furosemide with midazolam or with monobasic potassium phosphate was physically incompatible. The $\mathrm{pH}$-dependent solubility of furosemide was the origin of the observed incompatibilities.

Conclusions Monobasic potassium phosphate is not compatible with furosemide in the concentration range used in our intensive care unit and should not be administered together in the same intravenous line. Other drug formulations buffered to a low pH should not be administered with furosemide solutions either.

\section{INTRODUCTION}

Physicochemical incompatibilities between intravenous drugs are a recurrent problem in intensive care units (ICUs), ${ }^{1}{ }^{2}$ where most of the drugs are administered continuously. Thus, despite the use of multilumen catheters, several drugs flow together in the same line. Poorly documented (in)compatibilities involve, among others, intravenous monobasic potassium phosphate $\left(\mathrm{KH}_{2} \mathrm{PO}_{4}\right)^{3}$ frequently used to supplement patients with hypophosphataemia or to rapidly compensate a hypercalcaemia.

Recently, significant white cloudy precipitates were observed in central intravenous catheters in our adult ICU. The patients concerned received four to eight drugs continuously in the same intravenous line (same lumen of the central venous catheter), including $\mathrm{KH}_{2} \mathrm{PO}_{4}$ (table 1). These patients also received furosemide, a drug solution known to be incompatible with many others due to its high $\mathrm{pH}^{3}{ }^{3}$

The aim of this study was to identify the origin of these incompatibilities.

\section{METHODS}

\section{Literature search}

A search for literature reports on incompatibilities between pairs of drugs administered simultaneously was performed. $^{3-5}$

\section{Visual assays}

Visual assays were performed to assess the compatibility between two drugs either in the absence of published information $\left(\mathrm{KH}_{2} \mathrm{PO}_{4}\right.$ with furosemide, heparin sodium, human insulin, midazolam, propofol or remifentanil) or when the literature provided controversial or incompatible results (furosemide with midazolam or magnesium sulfate and $\mathrm{KH}_{2} \mathrm{PO}_{4}$ with magnesium sulfate).

The tests were performed in transparent and colourless glass test tubes with a flat base. The concentrations and solvents chosen were the same as commonly used in our adult ICU (figure 1).

For each pair of drugs, four different tests were performed, namely: (A) $1 \mathrm{~mL}+1 \mathrm{~mL}$, no mixing, (B) $1 \mathrm{~mL}+1 \mathrm{~mL}$, mixing, (C) $1 \mathrm{~mL}+4 \mathrm{~mL}$, mixing, (D) $4 \mathrm{~mL}+1 \mathrm{~mL}$, mixing.

Duplicate combinations were prepared, with permutation of the addition order for the two combinations. The 1:1 ratio was chosen according to Allen et al. ${ }^{6}$ The 1:4 and 4:1 ratios were used to simulate cases where one of the two drugs is administered faster than the other and will thus reach higher concentrations at the tubing Y-site. The two drugs were mixed with a Mini Vortexer VWR for $5 \mathrm{~s}$. The 1:1 ratio test without mixing was performed to better simulate a Y-injection where mixing is not always immediate. Glass tubes were closed and maintained at room temperature for $24 \mathrm{~h}$ without light protection. Solutions were examined for any visible change after $6 \mathrm{~min}, 15$ $\min , 30 \mathrm{~min}, 1 \mathrm{~h}, 2 \mathrm{~h}, 4 \mathrm{~h}$ and $24 \mathrm{~h}$ and the $\mathrm{pH}$ was measured after $15 \mathrm{~min}, 30 \mathrm{~min}, 1 \mathrm{~h}$ and $2 \mathrm{~h}$. The tubes were inspected macroscopically, first against a white background to look for any colour appearance and then against a black background with polarised light to look for a precipitate, opacity or creaming of lipidic solutions. ${ }^{7}$ Drugs were considered compatible when no change was detectable within $24 \mathrm{~h}$.

\section{Determination of the solubility of furosemide as a function of $\mathrm{pH}$}

Among all checked drugs, furosemide is known to be a frequent source of incompatibilities. ${ }^{3}$ Due to its acidic properties, it must be solubilised in a slightly basic solution and is often incompatible with drugs soluble in slightly acidic solutions. We therefore determined the $\mathrm{pH}$-dependent solubility of furosemide. Phosphate buffers $\left(\mathrm{Na}_{2} \mathrm{HPO}_{4} \cdot 2 \mathrm{H}_{2} \mathrm{O}\right.$, Merck, Germany and citric acid, Hänseler AG, Switzerland) were prepared and adjusted at $\mathrm{pH} 2.00$ $\pm 0.05,3.00 \pm 0.05,4.00 \pm 0.05,5.00 \pm 0.05,6.00$ 
Table 1 Drugs administered in the same intravenous line in six patients in the catheter of whom a white cloudy precipitate was observed.

\begin{tabular}{|c|c|c|c|c|c|c|c|c|}
\hline & $\begin{array}{l}\text { Human } \\
\text { insulin } \\
1 \mathrm{UI} / \mathrm{mL} \text {, } \\
\text { D5W }\end{array}$ & $\begin{array}{l}\text { Potassium } \\
\text { chloride } \\
1 \mathrm{mmol} / \mathrm{mL} \text {, } \\
\text { undiluted }\end{array}$ & $\begin{array}{l}\text { Monobasic } \\
\text { potassium } \\
\text { phosphate } \\
\text { variable } \\
\text { concentration, NS }\end{array}$ & $\begin{array}{l}\text { Furosemide } \\
\text { sodium } \\
\text { variable } \\
\text { concentration, NS }\end{array}$ & $\begin{array}{l}\text { Heparin } \\
\text { sodium } \\
416.7 \mathrm{UI} / \mathrm{mL} \text {, } \\
\text { NS }\end{array}$ & $\begin{array}{l}\text { Magnesium } \\
\text { sulfate } \\
\text { variable } \\
\text { concentration, } \\
\text { NS }\end{array}$ & Other & Solute \\
\hline Patient 1 & $x$ & $x$ & $\begin{array}{l}\mathrm{X} \\
0.8 \mathrm{mmol} / \mathrm{mL}\end{array}$ & $\begin{array}{l}X \\
10 \mathrm{mg} / \mathrm{mL}\end{array}$ & $x$ & $\begin{array}{l}X \\
20 \mathrm{mg} / \mathrm{mL}\end{array}$ & $\mathrm{G} 20 \%$ & NS \\
\hline Patient 2 & & $x$ & $\begin{array}{l}X \\
1.0 \mathrm{mmol} / \mathrm{mL}\end{array}$ & $\begin{array}{l}X \\
1 \mathrm{mg} / \mathrm{mL}\end{array}$ & $x$ & & & GS \\
\hline Patient 3 & & $x$ & $\begin{array}{l}\mathrm{X} \\
0.4 \mathrm{mmol} / \mathrm{mL}\end{array}$ & $\begin{array}{l}X \\
1 \mathrm{mg} / \mathrm{mL}\end{array}$ & & $\begin{array}{l}X \\
18 \mathrm{mg} / \mathrm{mL}\end{array}$ & $\begin{array}{l}\text { propofol } 2 \% \text {, undiluted } \\
\text { midazolam } 1 \mathrm{mg} / \mathrm{mL} \text {, D5W } \\
\text { remifentanil } 0.12 \mathrm{mg} / \mathrm{mL} \text {, D5W }\end{array}$ & NS \\
\hline Patient 4 & $x$ & $x$ & $\begin{array}{l}X \\
0.6 \mathrm{mmol} / \mathrm{mL}\end{array}$ & $\begin{array}{l}X \\
1 \mathrm{mg} / \mathrm{mL}\end{array}$ & $x$ & & & NS \\
\hline Patient 5 & $x$ & $x$ & $\begin{array}{l}\mathrm{X} \\
0.2 \mathrm{mmol} / \mathrm{mL}\end{array}$ & $\begin{array}{l}X \\
5 \mathrm{mg} / \mathrm{mL}\end{array}$ & $x$ & $\begin{array}{l}X \\
20 \mathrm{mg} / \mathrm{mL}\end{array}$ & propofol $2 \%$, undiluted & NS \\
\hline Patient 6 & & & $\begin{array}{l}X \\
0.2 \mathrm{mmol} / \mathrm{mL}\end{array}$ & $\begin{array}{l}X \\
5 \mathrm{mg} / \mathrm{mL}\end{array}$ & $x$ & $\begin{array}{l}X \\
8 \mathrm{mg} / \mathrm{mL}\end{array}$ & & NS \\
\hline
\end{tabular}

$\pm 0.05,7.00 \pm 0.05$ and $8.00 \pm 0.05$; other buffers $\left(\mathrm{Na}_{2} \mathrm{CO}_{3}\right.$, Merck, Germany and $\mathrm{NaHCO}_{3}$, Sigma-Aldrich, USA) were prepared for $\mathrm{pH}=9.00 \pm 0.05$ and $\mathrm{pH}=10.00 \pm 0.05 .^{8}$ About $600 \mathrm{mg}$ of furosemide powder was added to $10.0 \mathrm{~mL}$ of each $\mathrm{pH}$ solution and agitated for $6 \mathrm{~h}$ for maximal dissolution. The solutions were then filtered with a $0.45 \mu \mathrm{m}$ PVDF membrane filter (Acrodisc PALL) and their $\mathrm{pH}$ adjusted to $8.00 \pm 0.05$ with $\mathrm{NH}_{3}$ 17.5 or $3.5 \%$ or $\mathrm{HCl} 0.5 \mathrm{~N}(\mathrm{pH}$ value close to that of Lasix solutions).

The concentration of furosemide in each solution was then measured by HPLC ${ }^{9}$ : HPLC Waters 2695 Alliance Separations Module (Waters Corp, USA) driven with the Empower Software; Symmetry C18 Guard Column $3.9 \times 20 \mathrm{~mm}$ (Waters) and Chromolith Performance RP-8e $100 \times 4.6 \mathrm{~mm}, 2 \mu \mathrm{m}$ (Merck, Deutschland) as stationary phase; $0.2 \mathrm{~g} \quad \mathrm{KH}_{2} \mathrm{PO}_{4}$ (Merck, Germany) $+0.25 \mathrm{~g}$ cetrimide (FeF Chemicals $\mathrm{A} / \mathrm{S}$ ) in
$70 \mathrm{~mL}$ water, $\mathrm{pH}$ adjusted to $7.0 \pm 0.05$ with $\mathrm{NH}_{3} 17.5 \%$ and addition of $30 \mathrm{~mL}$ propanol as mobile phase; flow rate of $1 \mathrm{~mL} /$ min; temperature of the column fixed at $30^{\circ} \mathrm{C}$; injected volume of $100 \mu \mathrm{L}$ for the $\mathrm{pH} 2, \mathrm{pH} 3$ and $\mathrm{pH} 4$ solutions, and $50 \mu \mathrm{L}$ for the other solutions; Waters 2996 photodiode array detector with a fixed length of wave of $238 \mathrm{~nm}$ as detector.

\section{RESULTS}

\section{Literature search}

According to the literature, only the simultaneous administration (Y-injection) of furosemide and midazolam or magnesium sulfate $^{510}$ is reported to have led to a precipitate, whereas data about the compatibility of magnesium sulfate with $\mathrm{KH}_{2} \mathrm{PO}_{4}{ }^{4} 5$ are controversial. Besides, there is no information on the compatibility of $\mathrm{KH}_{2} \mathrm{PO}_{4}$ with furosemide, heparin sodium, human insulin, midazolam, propofol or remifentanil.

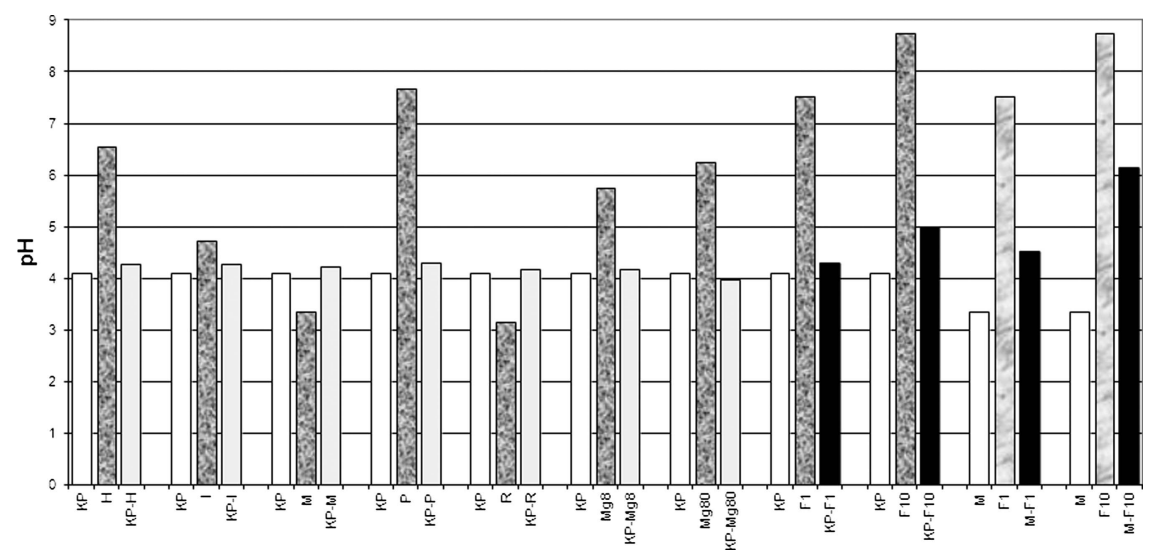

Figure $1 \mathrm{pH}$ values of single-drug solutions and their pairwise mixtures. For each mixture, the $\mathrm{pH}$ represented here is the mean of the $\mathrm{pH}$ values measured at $15 \mathrm{~min}, 30 \mathrm{~min}, 1 \mathrm{~h}$ and $2 \mathrm{~h}$, for the 1:1 mixed test. The black bars correspond to the formation of a precipitate. Standard deviations were small $(\leq 0.1)$ and are not shown. Key: (1) $\mathrm{KP}=$ monobasic potassium phosphate $\mathrm{KH}_{2} \mathrm{PO}_{4}$ (Potassium Phosphate $\mathrm{B}$ Braun $1 \mathrm{mmol} / \mathrm{mL}, 10 \mathrm{~mL}$ ) undiluted ( $\mathrm{pH}=4.10)$. (2) $\mathrm{H}=$ heparin sodium (Liquemine Roche $5000 \mathrm{UI} / \mathrm{mL}, 5 \mathrm{~mL}) 416.7 \mathrm{UI} / \mathrm{mL}$ in NS (NaCl $0.9 \%)(\mathrm{pH}=6.55)$. (3) I=human insulin (Actrapid HM Novo Nordisk $100 \mathrm{Ul} / \mathrm{mL}, 10 \mathrm{~mL}$ ) $1 \mathrm{UI} / \mathrm{mL}$ in dextrose $5 \%$ (pH=4.73). (4) M=midazolam (Dormicum Roche $5 \mathrm{mg} / \mathrm{mL}, 3 \mathrm{~mL}$ ) $1 \mathrm{mg} / \mathrm{mL}$ in dextrose $5 \%$ ( $\mathrm{pH}=3.35$ ). (5) $\mathrm{P}=$ propofol (Disoprivan PFS AstraZeneca $20 \mathrm{mg} / \mathrm{mL}, 50 \mathrm{~mL}$ ) undiluted ( $\mathrm{pH}=7.67)$. (6) R=remifentanil hydrochloride (Ultiva GSK $5 \mathrm{mg}$ ) $0.1 \mathrm{mg} / \mathrm{mL}$ in dextrose $5 \%$ (pH=3.14). (7) Mg8=magnesium sulfate (Magnesium Sulfate Bichsel $100 \mathrm{mg} / \mathrm{mL}, 10 \mathrm{~mL}$ ) $8 \mathrm{mg} / \mathrm{mL}$ in $\mathrm{NaCl} 0.9 \%$ (pH=5.75). (8) Mg80=magnesium sulfate (Magnesium Sulfate Bichsel $100 \mathrm{mg} / \mathrm{mL}, 10 \mathrm{~mL}) 83.3 \mathrm{mg} / \mathrm{mL}$ in $\mathrm{NaCl} 0.9 \%$ (pH=6.24). (9) F1=furosemide sodium (Lasix Aventis Pharma $10 \mathrm{mg} / \mathrm{mL}, 2 \mathrm{~mL}$ ) $1 \mathrm{mg} / \mathrm{mL}$ in NaCl 0.9\% (pH=7.53). (10) F10=furosemide sodium (Lasix Aventis Pharma $10 \mathrm{mg} / \mathrm{mL}, 2 \mathrm{~mL})$ undiluted $(\mathrm{pH}=8.74)$. 


\section{Visual assays}

$\mathrm{KH}_{2} \mathrm{PO}_{4}$ and furosemide showed physical incompatibility, with the formation within a few minutes of a dense cloudy white precipitate. Concentration seemed to play a role, since the precipitate appeared more rapidly with the $10 \mathrm{mg} / \mathrm{mL}$ than with the $1 \mathrm{mg} / \mathrm{mL}$ furosemide solution. Besides, the mixing of midazolam with furosemide also led to a rapid precipitation, while the mixture of magnesium sulfate with $\mathrm{KH}_{2} \mathrm{PO}_{4}$ was visually compatible for $24 \mathrm{~h}$, at least at the tested concentrations, as well as the mixture of $\mathrm{KH}_{2} \mathrm{PO}_{4}$ with the other tested drugs.

The results of $\mathrm{pH}$ measurements are represented in figure 1, showing a dramatic $\mathrm{pH}$ change between the mixture and one or both drug solution(s) in cases a precipitate was visible (ie, furosemide-midazolam and $\mathrm{KH}_{2} \mathrm{PO}_{4}$-furosemide). Three other mixtures, namely $\mathrm{KH}_{2} \mathrm{PO}_{4}$ with heparin sodium, magnesium sulfate or propofol, also showed a significant $\mathrm{pH}$ change, but without precipitation or emulsion break in the case of propofol lipid emulsion.

\section{Determination of the solubility of furosemide as a function of $\mathrm{pH}$}

Our investigation showed as expected from the structure of furosemide that its solubility was indeed $\mathrm{pH}$-dependent (practically insoluble at $\mathrm{pH}<6,10 \mathrm{mg} / \mathrm{mL}$ at $\mathrm{pH}=7,15 \mathrm{mg} / \mathrm{mL}$ at $\mathrm{pH}=8$ and $35 \mathrm{mg} / \mathrm{mL}$ at $\mathrm{pH}=9$ and 10$)$.

\section{DISCUSSION}

Of the pairs investigated, only two appeared to be incompatible, namely (A) midazolam and furosemide, already described in this way in the literature, and (b) $\mathrm{KH}_{2} \mathrm{PO}_{4}$ and furosemide. This latter incompatibility was unpublished and may explain the precipitates observed in the ICU patients' catheters. For patient 3, midazolam may even have worsened the phenomenon, being also incompatible with furosemide.

Furosemide is an organic acid with a pKa of 3.9. The drug is much more soluble at neutral and basic $\mathrm{pH}$ values where its anionic form predominates. The solubility of furosemide is comparable with that of other sparingly soluble ionisable drugs presented by Avdeef ${ }^{11}$ and, in our study, the concentrations of furosemide measured at low $\mathrm{pH}(\mathrm{pH}=2$ and $\mathrm{pH}=6)$ were similar to those described by Beyers. ${ }^{12}$ Even if the nature of the buffer may be a significant factor in drug solubility, ${ }^{13} \mathrm{pH}$ appears as the only critical factor in furosemide solubility. ${ }^{14}$ Lasix for injection, which has a high $\mathrm{pH}$ (8.90), will thus be incompatible with acidic solutions. In our case, addition of acidic solutions, either $\mathrm{KH}_{2} \mathrm{PO}_{4} 1 \mathrm{mmol} / \mathrm{mL}(\mathrm{pH}=4.10)$ or midazolam $1 \mathrm{mg} / \mathrm{mL}$ in dextrose $5 \%(\mathrm{pH}=3.35)$ lowered the $\mathrm{pH}$ enough for part of the drug to precipitate.

According to literature, furosemide is indeed incompatible with acidic drug formulations (eg, ciprofloxacine $(\mathrm{pH}=3.9-4.5)$, milrinone $(\mathrm{pH}=3.2-4.0)$, gentamicin $(\mathrm{pH}=3.0-5.5)$, labetalol $(\mathrm{pH}=3.0-4.0)$, vinorelbine $(\mathrm{pH}=3.5)$ and gemcitabine $(\mathrm{pH}=2.7-3.3))(3)$. In contrast, formulations with neutral or basic $\mathrm{pH}$ are compatible with furosemide (eg, tirofiban $(\mathrm{pH}=6.5)$, dexamethasone $(\mathrm{pH}=8.0-9.0)$, ceftazidime $(\mathrm{pH}=6.0-8.0)) .^{3}$

The incompatibility between $\mathrm{KH}_{2} \mathrm{PO}_{4}$ and furosemide was added to the Table of Drug Incompatibilities we provide to the nursing staff at the ICU. Since $\mathrm{KH}_{2} \mathrm{PO}_{4}$ and furosemide are often administered continuously, the only way to avoid an incompatibility is to separate the two drugs in different lines. The use of an alternative phosphate salt yielding a higher $\mathrm{pH}$ (eg, sodium glycerophosphate, $\mathrm{pH}=7.4$ ) could also be considered.

The other solutions producing an important shift in $\mathrm{pH}$ without formation of a precipitate indicate that the solubilities of heparin sodium, magnesium sulfate and propofol are not $\mathrm{pH}$-dependent. Finally, the reported incompatibility of magnesium sulfate with potassium phosphate ${ }^{1}$ could not be reproduced in this study, possibly due to different concentrations or other factors. Under our conditions, no precipitate was apparent and this association was considered as compatible, in agreement with another report. ${ }^{2}$

\section{CONCLUSION}

$\mathrm{KH}_{2} \mathrm{PO}_{4}$ is not compatible with furosemide in the concentration ranges used in our ICU and should not be administered together in the same intravenous line. Other drug formulations buffered to a low $\mathrm{pH}$ should not be administered with furosemide solutions either.

Contributors This paper was reviewed and approved by all named authors, and each contributed significantly to the publication.

Competing interests None.

Provenance and peer review Not commissioned; externally peer reviewed.

\section{REFERENCES}

1 Bertsche T, Mayer $Y$, Stahl $R$, et al. Prevention of intravenous drug incompatibilities in an intensive care unit. Am J Health Syst Pharm 2008;65:1834-40.

2 Tissot E, Cornette $C$, Demoly $P$, et al. Medication errors at the administration stage in an intensive care unit. Intensive Care Med 1999:25:353-9.

3 Trissel LA. Handbook on injectable drugs. 16th edn. Bethesda: ASHP, 2011.

4 King guide to parenteral admixtures [online version]. Napa: King Guide Publications, Inc., 2012.

5 Trissel LA, Leissing NC. Trissel's tables of physical compatibility. 1st edn. Lake Forest: MultiMatrix, Inc., 1996.

6 Allen LV, Levinson RS, Phisutsinthop D. Compatibility of various admixtures with secondary additives at $\mathrm{Y}$-injection sites of intravenous administration sets. Am J Hosp Pharm 1977;34:939-43.

7 European pharmacopeia. 7th edn. Strasbourg: European Directorate for the Quality of Medicines and HealthCare (edqm), 2011. Chapters 2.2.1: Clarity and degree of opalescence of liquids, visual method; and 2.2.2: Degree of coloration of liquids.

8 Wissenschaftliche Tabellen Geigy, haematology and human genetics. 8th edn. Basel: Ciba-Geigy Limited, 1979:60-2.

9 European Pharmacopeia. 7th edn. Strasbourg: European Directorate for the Quality of Medicines and HealthCare (edqm), 2011. monograph of furosemide.

10 Bhaskara RJ, Poonam S. Compatibility of Parenteral furosemide with seventeen secondary drugs used in standard concentrations. Int I Pharm Compound 2011;15:259-61.

11 Avdeef A. Solubility of sparingly-soluble ionizable drugs. Adv Drug Deliv Rev 2007:59:568-90

12 Beyers H, Malan SF, van der Watt JG, et al. Structure-solubility relationship and thermal decomposition of furosemide. Drug Dev Ind Pharm 2000;26:1077-83.

13 Narazaki R, Sanghvi R, Yalkowsky SH. Estimation of drug precipitation upon dilution of pH-controlled formulations. Mol Pharm 2007;4:550-5.

14 Shah KA, Das Gupta V, Stewart KR. Effect of pH, chlorobutanol, cysteine hydrochloride, ethylenediaminetetraacetic acid, propylene glycol, sodium metabisulfite, and sodium sulfite on furosemide stability in aqueous solutions. J Pharm Sci 1980;69:594-6. 